\title{
Physicochemical quality and consumer discrimination of industrial and traditional fermented sausages
}

\author{
Marlice Bonacina $^{1}$ (D) Gabriela Smolinski da Silva ${ }^{1}$ (D) Marina Leite Mitterer-Daltoé ${ }^{*}$ \\ ${ }^{1}$ Instituto Federal de Educação, Ciência e Tecnologia do Rio Grande do Sul, Erechim, RS, Brasil. \\ ${ }^{2}$ Universidade Tecnológica Federal do Paraná (UTFPR), 85503-390, Pato Branco, PR, Brasil. E-mail: marinadaltoe@utfpr.edu.br \\ ${ }^{*}$ Corresponding author.
}

ABSTRACT: Salami tipo Italiáno ("Italian Salami”) and Linguiça Colonial ("Colonial Sausage”) are fermented sausages widely consumed in southern Brazil and commonly confused by consumers. Colonial sausages often characterized by greater diversity of physicochemical and sensory qualities, which often can weaken a product's identity. The aim of the present study was to evaluate the description and discrimination of brands of Italian Salami and Colonial Sausage using the "check-all-that-apply" technique by consumers and in parallel to relate the sensory perception to the physicochemical qualities of the fermented sausages. Results revealed a lack of physicochemical and sensory standardization for the Colonial Sausage brands (traditional). Sensory evaluations were most effective for discriminating industrial and traditional sausages. Through the check-all-that apply technique, consumers described and discriminated the samples, and set a standard for better hedonic acceptance of fermented sausages.

Key words: cata, colonial sausage, consumers, italian salami, sensory profile.

Qualidade físico-química e discriminação pelo consumidor de salames industriais e coloniais

RESUMO: Salame Tipo Italiano e Linguiça Colonial são embutidos fermentados largamente consumidos na região sul do Brasil e comumente confundidas pelos consumidores. Com caráter tradicional, a Linguiça Colonial é frequentemente caracterizada por apresentar maior diversidade nas características físico-químicas e sensoriais, o que muitas vezes pode vir ao desencontro do fortalecimento de uma identidade. O objetivo do presente estudo foi avaliar a descrição e a discriminação de Salame Tipo Italiano e de Linguiça Colonial por consumidores, por meio do uso da técnica Check all that apply; e de forma paralela relacionar a percepção sensorial às qualidades físico químicas dos embutidos fermentados. Os resultados revelaram falta de padronização físico-química e sensorial para as Linguiças Coloniais. As avaliações sensoriais foram mais eficazes para a discriminação dos embutidos fermentados. Os consumidores, por meio da técnica Check-all-that apply, descreveram e discrimnaram as amostras, além de definirem um padrão de melhor aceitação hedônica para embutidos fermentados.

Palavras-chave: cata, linguiça colonial, consumidores, salame italiano, perfil sensorial.

\section{INTRODUCTION}

Italian Salami and Colonial Sausage are fermented meat products that are widely consumed in southern Brazil (BERTOL et al., 2012; CIROLINI et al., 2010; DALLA-SANTA et al., 2012; MARANGONI \& FERNANDES, 2011; MARANGONI \& MOURA, 2011; PARUSSOLO et al., 2019). Italian Salami is mainly produced by large industries, and according to the Technical Regulation for Identity and Quality (BRASIL, 2000), it is defined as a meat product which must have the following mandatory ingredients: pork (minimum 60\%), salt and nitrite and/or nitrate, along with adjuvants as starters of fermentation. This sausage type is characterized by uniformity in chemical composition and sensory characteristics (BIS-SOUZA et al., 2019; HAMMES; KNAUF, 1994; LORENZO et al., 2014).

Colonial sausage is popularly called salami as well (CIROLINI et al., 2010) and often confused with Italian Salami. It is a traditional meat product commonly marketed as an artisanal rural product (BERTOL et al., 2012). Its standard of identity and quality are subject to the same regulations as 
Italian Salami. What differentiates them in terms of ingredients is the obligation to be made only with pork. The more artisanal character gives this meat product common characteristics of traditional fermented sausages, with a wider diversity of chemicals and consequently sensory characteristics, often a result of the absence of a starter (CRUXEN et al., 2018; RASON et al., 2007).

Beyond the influence of starters, the lack of standardization in the different stages of preparation can also influence the physicochemical and sensory characteristics of the product. Variations in physicochemical parameters such as moisture, color, $\mathrm{pH}$ and acidity have been recorded as a result of different technological processes of making fermented sausages (BIS-SOUZA et al., 2019; FRANÇOIS et al., 2009; YUCA et al., 2019; ZANARDI et al., 2002).

Despite having large diversity of quality, traditional sausages are characterized by their strong identity (KÜHNE et al., 2010). This characteristic increases the sales of small rural producers in the region, not only because it is a popular product of the local culture, but also because it adds value to the pork meat widely produced in southern Brazil as a result of the Italian and German colonization (BERTOL et al., 2012).

However, the success of a product in the market is a result of the standardization of its characteristics, since consumers who feel satisfied want to consume the same product again. For this reason, according to RASON et al.(2007) there is concern that the diversity found in traditional sausages may alienate consumers who are used to consuming industrial products with standardized sensory traits.

Previous studies involving Italian Salami (CIROLINI et al., 2010; MARANGONI \& FERNANDES, 2011; MARANGONI \& MOURA, 2011) and Colonial Sausage (BERTOL et al., 2012; DALLA-SANTA et al., 2012) in southern Brazil have been published. However, all highlighted microbiological, chemical and physicochemical results except the research of MARANGONI \& MOURA(2011), who evaluated the sensory profile of Italian Salami with coriander (Coriandrum sativum L.) essential oil through the classic method of quantitative descriptive analysis by trained assessors.

Considering that sensory diversity differentiates "traditional" and "industrial" products among consumers (RASON et al., 2007) and that no study has been conducted to describe the sensory profile of industrial and traditional fermented sausages from southern Brazil by untrained assessors, the aim of this study was to evaluate the description and discrimination of brands of Italian Salami and Colonial Sausage using the check-all-that-apply technique. In order to better understand consumers' perceptions, and to establish correlation with sensory descriptors, physicochemical and hedonic analyses were also applied to the samples of fermented sausage.

\section{MATERIALS AND METHODS}

\section{Samples}

Once the samples were spicy, fatty and intense flavor; and the sensory analysis needed occurred in a single session (MININ, 2006), four brands (two of Italian Salami and two of Colonial Sausage) were used. For physicochemical analysis a total of 12 samples were used, 6 for Italian Salami (3 for each brand) and 6 for Colonial Sausage (3 for each brand). For sensory analysis, a total of 16 samples were used, 8 for Italian Salami (4 for each brand) and 8 for Colonial Sausage (4 for each brand). In total 28 samples were analyzed.

The samples were purchased at random in supermarkets in the municipality of Erechim, located in the state of Rio Grande do Sul, Brazil. After, were identified according to batch and sent to the laboratories of the Federal Institute of Science and Technology Education of Rio Grande do Sul (IFRS), Erechim campus, to perform the physicochemical and sensory analyses. For physicochemical analysis, the aim was to analyze different batches of the same brand. In contrast, for sensory tests, the aim was to keep the same batch for each brand.

\section{Physicochemical analysis}

The moisture, $\mathrm{pH}$ and acidity were measured according to the method described by AOAC (2012). The evaluation of color intensity followed the method proposed by TAPP III et al. (2011). The color measurement of fermented sausages was performed using the CIELAB scale $\left(L^{*}, a^{*}, b^{*}\right)$ using a Konica Minolta CR-410 Chroma Meter (portable colorimeter). All analyses were performed in triplicate.

\section{Sensory analysis \\ Consumer panel}

The study was conducted in Erechim, Rio Grande do Sul. A total of 50 consumers took part in the study (20-55 years old). All participants stated they consumed fermented sausages at least once a month. The participants were invited to participate and gave informed consent according to rules approved by the Ethics Committee of IFRS, under no. 79741517.9.0000.8024. 


\section{Samples}

The fermented sausages were cut into slices $5 \mathrm{~mm}$ thick. The four samples were presented to consumers following a balanced rotation, in monadic sequence. Samples were served in small containers coded with a random 3-digit sequence (ARSLAN \& SOYER, 2018). Tests were performed in a sensory analysis laboratory according to ISO 8589 (ISO, 2007).

\section{Check-all-that-apply (CATA) questions}

To evaluate the sensory profile of fermented sausages, CATA questionnaire composed of 19 statements was applied. For each statement there was an opposite one, with the intention of obtaining reliable results. The responses of participants who marked a statement, as well as its opposite were eliminated. The statements were presented in four randomly selected orders (four versions of the questionnaire), to prevent errors in function of the order (ARES \& JAEGER, 2013).

The 19 descriptors used in the questionnaire were composed of descriptive sensory attributes based on a previous study (MARANGONI\& MOURA, 2011) and composed of hedonic terms, to generate a perception of acceptance.

\section{Data analysis}

Data from physicochemical and sensory results were evaluated regarding one-dimensional and multidimensional aspects. Data from physicochemical results were evaluated regarding one-dimensional aspects by ANOVA and regarding multidimensional aspects by principal component analysis (PCA). The
PCA was performed on the correlation matrix of the physicochemical qualities averaged across samples. The data were analyzed using Statistica 12.7.

Data from CATA questionnaire were evaluated regarding one-dimensional aspects by the nonparametric Cochran $\mathrm{Q}$ test and regarding multidimensional aspects by correspondence analysis (CA). Frequency of use of each sentence was determined by counting the number of consumers that checked that term to describe each fermented sausage sample. The data were analyzed using the XLSTAT ${ }^{\circledR}$ 2018.1.49630 software (Addinsoft ${ }^{\mathrm{TM}}$ ).

\section{RESULTS}

Physicochemical and sensory characterization by one-dimensional aspects

Tables 1 and 2 present; respectively, results of physicochemical and sensory characterization of fermented sausages by one-dimensional aspects. Data on each of the six physicochemical quality indicators were submitted to ANOVA. Table 1 shows that the product effect (fermented sausages) was not significant just for the $\mathrm{L}^{*}$ parameter. For the other quality indicators, significant effects of fermented sausages were verified and these differences between fermented sausages can be better visualized by the Tukey mean difference test (Table 1).

If P-value from ANOVA indicated the $\mathrm{L}^{*}$ parameter as the only one, that not had a quality indicator to discriminate the samples. The Tukey test shows which samples were distinguished regarding the other parameters, and even suggested which physicochemical quality indicators could better

Table 1 - P-values from ANOVA for fermented sausages regarding each physicochemical quality parameter; and means comparison by Tukey test for each parameter.

\begin{tabular}{|c|c|c|c|c|c|}
\hline $\begin{array}{l}\text { Physicochemical } \\
\text { quality }\end{array}$ & ${ }^{*} \mathrm{P}$ & $\begin{array}{c}\text { Italian } \\
\text { Salami A }\end{array}$ & $\begin{array}{c}\text { Italian } \\
\text { Salami B }\end{array}$ & Colonial Sausage A & Colonial Sausage B \\
\hline $\mathrm{L}^{*}$ & 0.074 & $52.64^{\mathrm{a}} \pm 3.75$ & $50.56^{\mathrm{a}} \pm 2.41$ & $51.87^{\mathrm{a}} \pm 2.96$ & $54.16^{\mathrm{a}} \pm 1.84$ \\
\hline$a^{*}$ & 0.0003 & $17.40^{\mathrm{b}} \pm 1.71$ & $17.80^{\mathrm{b}} \pm 0.60$ & $14.23^{\mathrm{a}} \pm 2.79$ & $17.34^{b} \pm 0.84$ \\
\hline$b^{*}$ & 0.0001 & $11.18^{\mathrm{a}} \pm 0.93$ & $11.29^{\mathrm{a}} \pm 0.47$ & $12.77^{b} \pm 0.95$ & $12.29^{\mathrm{b}} \pm 0.13$ \\
\hline $\mathrm{pH}$ & 0.0001 & $4.84^{\mathrm{a}} \pm 0.20$ & $5.81^{\mathrm{b}} \pm 0.12$ & $5.57^{b} \pm 0.17$ & $5.30^{\mathrm{a}} \pm 0.24$ \\
\hline Acidity (\%) & 0.0001 & $1.17^{\mathrm{cb}} \pm 0.05$ & $0.99^{\mathrm{ab}} \pm 0.08$ & $0.95^{\mathrm{a}} \pm 0.19$ & $1.32^{\mathrm{c}} \pm 0.18$ \\
\hline Moisture (\%) & 0.0001 & $33.95^{\mathrm{a}} \pm 2.43$ & $31.68^{\mathrm{a}} \pm 7.73$ & $59.38^{c} \pm 6.17$ & $42.49^{b} \pm 3.24$ \\
\hline
\end{tabular}

*P-values from ANOVA for each physicochemical quality parameter. 0.0001 means that the P-value is less than 0.0001 . Means followed by equal letters in the same row do not differ significantly by the Tukey test $(\mathrm{P} \geq 0.05)$. $\mathrm{N}=3$. 
discriminate between industrial and traditional fermented sausages. For the present study, the parameters $\mathrm{b}^{*}$ and moisture were possibly the indicators where the greatest differences were reported between Italian Salami (industrial) and Colonial Sausage (traditional).For parameter $b$ * (blue and yellow), differences were verified between Italian Salami and Colonial Sausage samples. There was no difference between the two salami brands and two sausage brands for this parameter. The lower $b$ * value recorded for Italian Salami is possibly related to the addition of starters in the formulation of these products. According to PÉREZ-ALVAREZ et al.,(1999) the parameter $b^{*}$ is a quality indicator that decreases during the fermentation of meat products, due to the high oxygen consumption by the added microorganisms; consequently, leading to a decrease of oxyglobin, which contributes considerably to the decrease of the $b^{*}$ value. Moreover, according to those authors, the reaction of nitric oxide with myoglobin to form nitrosomyoglobin also reduced this parameter.

Regarding moisture, this parameter not only differed between the samples of Italian Salami and Colonial Sausage, but also indicated standardization of this quality indicator for industrial sausages and the lack of standardization for traditional sausages. This outcome is largely due to the $35 \%$ maximum moisture content requirement set by Brazilian regulations for Italian Salami (BRASIL, 2000); and the absence of a tolerance limit for this quality indicator in the technical regulations of Colonial Sausage (BRASIL, 2000). The fact that Colonial Sausage does not have officially specified moisture content explains the wide variation in the results obtained between the two brands, as well as the higher moisture content than was found for Italian Salami. Previous studies have reported high and varied moisture contents in Colonial Sausage brands throughout Brazil. (GOTTARDO et al., 2011; SIPP $\&$ TONIAL, 2017), which makes this variation not only a characteristic inherent to the product, but also makes moisture a characteristic with wide limits of tolerance. And as well known, variations in moisture content affect other control parameters. This effect can be clearly seen by analyzing the parameter a * (red and green). Colonial Sausage B, which had the highest moisture content, presented the lowest value of $\mathrm{a}^{*}$ (14.23), and possibly the shortest maturation time, which leads to a reduction in the intensity of the red color. According to ZANARDI et al.(2002), during the curing process, the reaction of myoglobin with

Table 2 - Results of the check-all-that-apply questionnaire. Frequencies of each attribute of fermented sausages.

\begin{tabular}{|c|c|c|c|c|c|}
\hline Sensory attributes & $\mathrm{P}^{*}$ & Italian Salami A & Italian Salami B & Colonial Sausage A & Colonial Sausage B \\
\hline A little salty & 0.000 & 0.040 (a) & 0.160 (a) & $0.440(\mathrm{~b})$ & $0.180(a b)$ \\
\hline Salty & 0.001 & $0.600(b)$ & $0.580(\mathrm{~b})$ & $0.280(a)$ & $0.540(b)$ \\
\hline Very salty & 0.000 & $0.320(\mathrm{~b})$ & 0.040 (a) & 0.040 (a) & 0.040 (a) \\
\hline Juicy & 0.005 & 0.220 (a) & $0.400(\mathrm{ab})$ & $0.540(\mathrm{~b})$ & $0.440(\mathrm{~b})$ \\
\hline Dry & 0.000 & $0.400(\mathrm{~b})$ & $0.320(\mathrm{~b})$ & 0 (a) & $0.080(a)$ \\
\hline Slightly spicy & 0.000 & 0.140 (a) & 0.220 (a) & $0.520(\mathrm{~b})$ & 0.220 (a) \\
\hline Spicy & 0.000 & $0.560(\mathrm{c})$ & $0.500(b c)$ & 0.180 (a) & $0.280(\mathrm{ab})$ \\
\hline Good appearance & 0.000 & $0.700(b)$ & $0.780(b)$ & 0.360 (a) & $0.680(b)$ \\
\hline Bad appearance & 0.000 & 0.080 (a) & $0.020(a)$ & $0.340(\mathrm{~b})$ & 0.020 (a) \\
\hline Slightly greasy & 0.165 & 0.240 (a) & 0.140 (a) & 0.100 (a) & 0.180 (a) \\
\hline Greasy & 0.001 & $0.260(a b)$ & 0.140 (a) & $0.500(\mathrm{~b})$ & $0.260(a b)$ \\
\hline Firm & 0.000 & $0.880(\mathrm{c})$ & $0.840(\mathrm{c})$ & 0.080 (a) & $0.540(\mathrm{~b})$ \\
\hline Not Firm & 0.000 & 0 (a) & 0.020 (a) & $0.680(\mathrm{~b})$ & 0.140 (a) \\
\hline Slightly smoky & 0.001 & $0.160(a b)$ & 0.100 (a) & $0.420(\mathrm{~b})$ & $0.220(a b)$ \\
\hline Smoky & 0.007 & $0.460(\mathrm{ab})$ & $0.600(\mathrm{~b})$ & 0.280 (a) & $0.440(a b)$ \\
\hline Deep Red Color & 0.002 & $0.620(\mathrm{~b})$ & $0.540(\mathrm{ab})$ & 0.340 (a) & $0.640(\mathrm{~b})$ \\
\hline Pale & 0.002 & $0.040(a)$ & $0.080(\mathrm{ab})$ & $0.280(\mathrm{~b})$ & $0.100(a b)$ \\
\hline Tasty & 0.000 & $0.620(\mathrm{~b})$ & $0.700(\mathrm{~b})$ & 0.240 (a) & $0.640(\mathrm{~b})$ \\
\hline Bad Taste & 0.002 & $0.020(\mathrm{ab})$ & 0 (a) & $0.180(\mathrm{~b})$ & $0.100(\mathrm{ab})$ \\
\hline
\end{tabular}

P-value from Cochran's Q test. Equal letters in the same row do not differ significantly present a meaningful difference, $(\mathrm{P} \geq 0.05)$.

Ciência Rural, v.50, n.7, 2020. 
nitric oxide forms the compound nitrosomyoglobin, the reddish pigment characteristic of cured meat.

Variations in chemical composition caused different sensory perceptions. These differences can be seen in table 2, which shows the frequency with which each of the terms of the CATA questionnaire was used to describe the fermented sausage samples.

Significant differences were reported in the frequencies of 18 out of the 19 terms of the CATA questionnaire used to describe samples, suggesting that this type of sensory technique was able to detect differences in consumers' perceptions of the fermented sausages. The results in table 2 also revealed that the terms most often cited to characterize and consequently discriminate $(\mathrm{p} \leq 0.05)$ the fermented sausages by consumers were: firm, good appearance, tasty, deep red color, smoky, and salty.

Slightly greasy was the unique attribute for which no significant difference was found, which indicated small differences in the samples. This attribute has weak discrimination power possibly because fat is a strongly characteristic ingredient of fermented sausages and is allowed in large quantities by regulations, up to $32 \%$ for Italian Salami and $30 \%$ for Colonial Sausage (BRASIL, 2000).

The standardization previously mentioned of Italian Salami was strongly supported by the descriptive sensory assessment of the consumers. Among the Italian Salami samples, a significant difference was verified only for the attribute "very salty", while between the samples of Colonial Sausage differences were registered for 8 of the 19 evaluated attributes. In this sense, both bands of Italian Salami were characterized by the main attributes salty, dry, spicy, good appearance, firm, smoky, deep red color and tasty. In turn, the definition of a common sensory profile for Colonial Sausages is more complicated.

Although, it was not possible to define a common profile between the two Colonial Sausage brands, it was possible to characterize each one through consumer evaluations. And while the physicochemical evaluations differentiated Colonial Sausage A from the other samples, these differences became more evident in the taste tests. Colonial Sausage A was mainly characterized by being not salty, slightly spicy, bad in appearance, not firm, not deep red color and not tasty. These results are possibly due to the higher moisture content of that sample.

Comparison of physicochemical and sensory descriptions by multidimensional aspects

In order to better visualize and understand consumers' sensory perception and to relate this to the physicochemical qualities of fermented sausages, physicochemical and sensory data are presented through the analysis of multidimensional results. Principal component analysis (PCA) was performed on the physicochemical data (Figure 1) and correspondence analysis (CA) was performed on data from the CATA questionnaire (Figure 2).

Biplots physicochemical and sensory data once again corroborated the standardization of Italian Salami and the lack of standardization of Colonial Sausage, since for both biplots the largest and first component/dimension separated Italian Salamis $\mathrm{A}$ and B and Colonial Sausage B from Colonial Sausage A. The visualization of biplots also allows a better understanding of the relationship of descriptive sensory qualities, physicochemical qualities and hedonic qualities of fermented sausages. It is clear from the analysis of the sample configurations that Colonial Sausage A was characterized by consumers mainly for its attributes "bad appearance", "not firm", "pale", "slightly smoky", "a little salty" and "bad taste" (Figure 2) and that these results are directly related to the physicochemical parameters moisture and $b^{*}$.

It is also worth mentioning that the data under multidimensional aspects allowed a better discrimination and description of the other samples, revealing that the Italian Salami B and Colonial Sausage B can be described as "salty", "smoky", "good appearance", "deep red color", and 'tasty", and these are directly related to the color parameter a *. Italian Salami A was mainly described as "dry", "firm", "spicy" and "slightly greasy", attributes directly related to the physicochemical parameters acidity and $\mathrm{L}^{*}$.

"Tasty" and "Bad taste" appear as important attributes for understanding the hedonic effect on consumers of the sensory characteristics of fermented sausages. From the results it can be stated that for consumers, a fermented sausage is tasty when it is salty, has smoky flavor and intense reddish color, which is indicative of good appearance. Conversely, a fermented sausage has bad taste when it is low in salt, has no smoke flavor, is not firm and is pale, which characterizes it as having "bad appearance".

\section{DISCUSSION}

The present research was based on the following hypotheses regarding the industrial and traditional fermented sausages with high consumption in southern Brazil and commonly confused by consumers: i) They would have distinct 


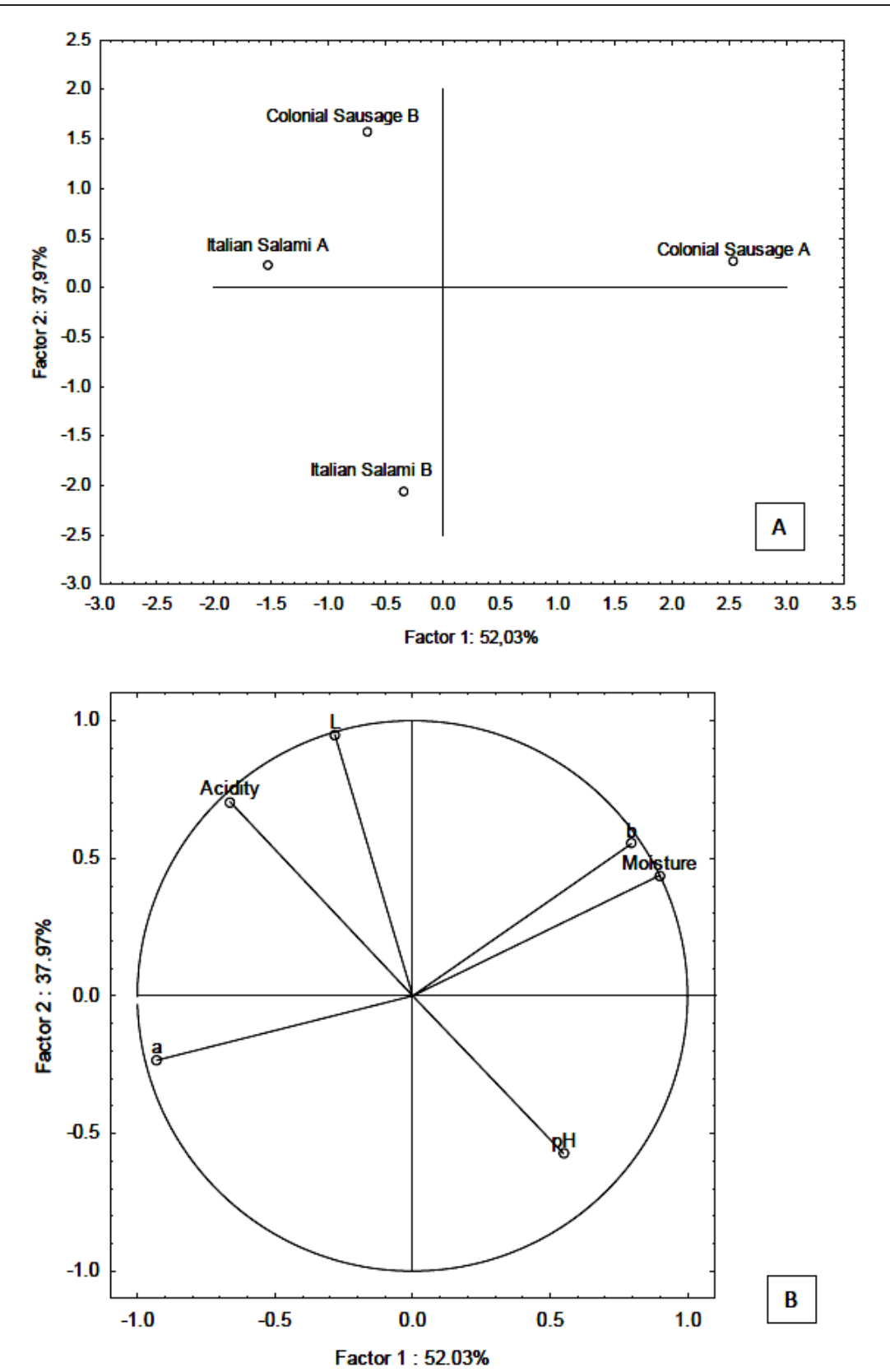

Figure 1 - A and B - Representation of samples (A) and physicochemical qualities (B) in the first two dimensions of Principal Component Analysis.

physicochemical and sensory characteristics; ii) Italian Salami (industrial) would show higher standardization in physicochemical and sensory quality indicators than Colonial Sausage (traditional); and iii) Consumers would be able to describe and discriminate samples of fermented sausages using the check-all-that-apply technique.

In order to verify the hypotheses, the data were analyzed in one-dimensional and multidimensional aspects. From the one-dimensional 


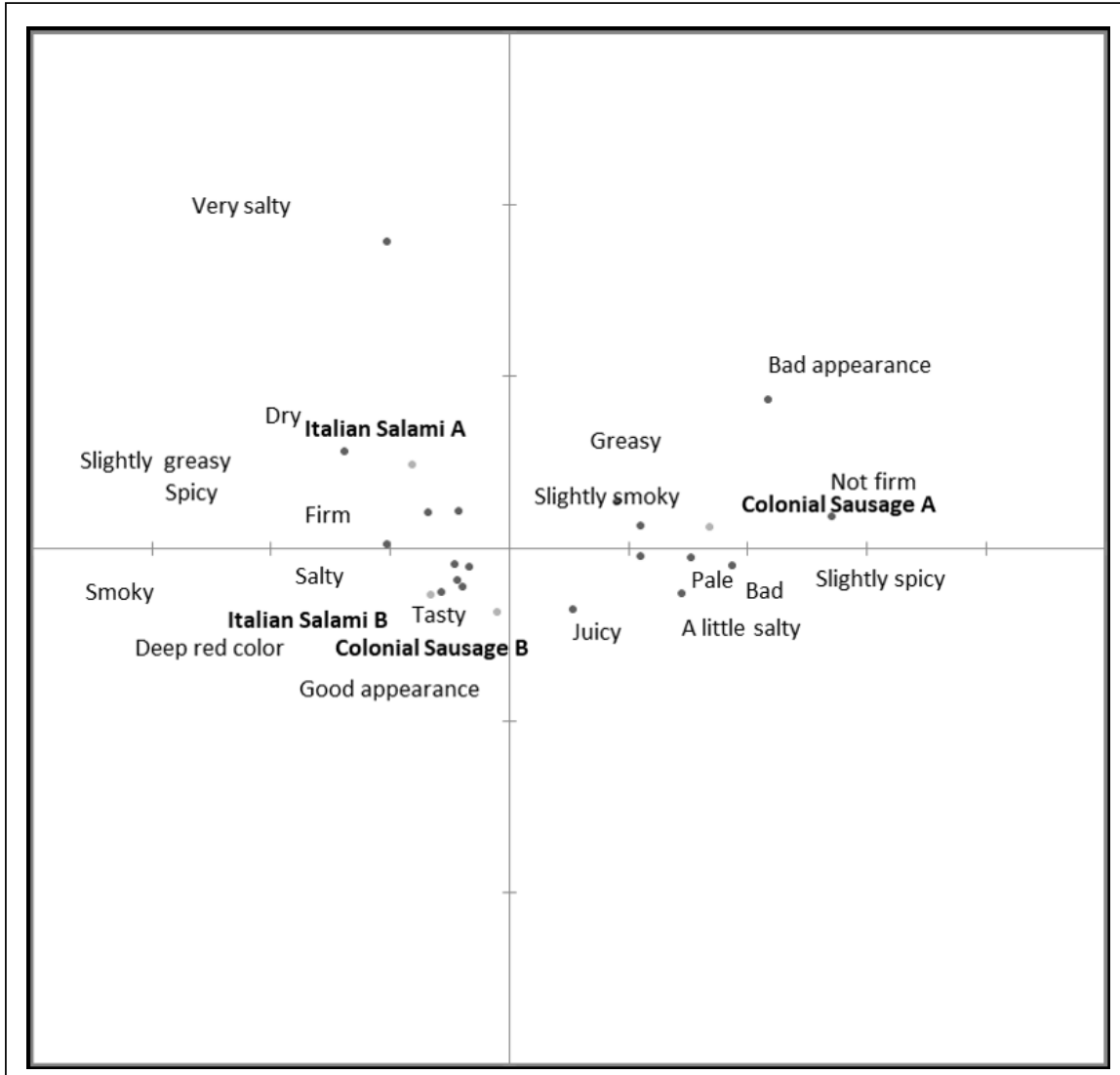

Figure 2 - Correspondence Analysis performed on data from CATA questions with consumers.

view point, the results of the application of ANOVA and the Tukey mean difference test for the physicochemical data revealed little difference between Italian Salami and Colonial Sausage, except for the moisture and $b^{*}$ quality indicators, which were different only for Colonial Sausage A, suggesting greater standardization of Italian Salami. When evaluating the sensory descriptions of fermented sausages performed on data from CATA questions by one-dimensional aspects, the differences between the samples became much more evident. The description of fermented sausages by consumers using the CATA technique not only allowed detecting sensory differences between Italian Salami and Colonial Sausage, but also allowed verifying a sensory pattern only for Italian Salami. In addition, the use of the technique highlighted the discriminatory ability of consumers for these often confused fermented sausages (BERTOL et al., 2012).

Although, corroborating the standard quality of Italian Salamis, the results when evaluated according to multidimensional aspects helped to better visualize sample discrimination for both physicochemical and sensory quality indicators. In addition, the joint analysis of biplots helped to better understand consumers' sensory perception and the physicochemical characteristics of fermented sausages, revealing that consumers prefer a "salty" fermented sausage with "smoky flavor", "good appearance" and "deep red color", for which purposes the product should mainly not have high moisture.

The three hypotheses; therefore, could not be fully confirmed. Although Italian Salamis presented higher physicochemical and sensory standardization (hypothesis i) and consumers successfully described and discriminated fermented sausages through CATA (hypothesis iii), no differences could be noted between Italian Salami and Colonial Sausage $\mathrm{B}$ in both physicochemical and sensory qualities (hypothesis ii), since the Colonial B sausage sample was similar $(p \geq 0.05)$ to both salami brands.

More than not confirming the hypotheses in full, the results point to the lack of standard for 
traditional fermented sausages, a fact that has been highlighted in other studies (PRADO et al., 2019; RASON et al., 2007) and attributed mainly to process diversification and the absence of starters. For this study, another element should be highlighted: the high variation in moisture, possibly due to the lack of reference to moisture limits in the regulations (BRASIL, 2000). And if Colonial Sausage is seen as a traditional fermented sausage with potential to strengthen the region's agribusinesses and small farmers, the insertion of moisture limits in the Technical Identity and Quality Regulation may be a strategic first step to assure product standardization and consequent consolidation of identity and consumer acceptance.

This standardization would better assure the quality and identity of traditional fermented sausages, but should always aim to preserve the unique character of this kind of food, since the maintenance the traits of traditional fermented sausages has been stressed as a prerequisite for innovations in traditional food products (KÜHNE et al., 2010).

\section{CONCLUSION}

The results of the present manuscript revealed a lack of physicochemical and sensory standardization for Colonial Sausages. The sensory evaluations were most effective for discriminating industrial and traditional sausages than physicochemical parameters. Through the check-all-that apply technique, consumers described and discriminated the samples, and set a standard for better hedonic acceptance of fermented sausages.

\section{ACKNOWLEDGEMENTS}

This work was financially supported by grants from Instituto Federal de Educação, Ciência e Tecnologia do Rio Grande do Sul- Campus Erechim. The authors also thank Universidade Tecnológica Federal do Paraná (UTFPR), Pato Branco and the Coordenação de Aperfeiçoamento de Pessoal de Nível Superior (CAPES).

\section{BIOETHICS AND BIOSSECURITY COMMITTEE APPROVAL}

The study was approved by the Ethics Committee of IFRS, under no. 79741517.9.0000.8024.

\section{DECLARATION OF CONFLICT OF INTERESTS}

The authors declare no conflict of interest. The founding sponsors had no role in the design of the study; in the collection, analyses, or interpretation of data; in the writing of the manuscript, and in the decision to publish the results.

\section{AUTHORS' CONTRIBUTIONS}

The authors contributed equally to the manuscript.

\section{REFERENCES}

Association of official analytical chemists - AOAC. Official methods of analysis. 19. ed. Maryland: [s.n.], 2012.

ARES, G.; JAEGER, S. R. Check-all-that-apply questions: Influence of attribute order on sensory product characterization. Food Quality and Preference, abr. 2013. v.28, n.1, p.141-153. Available from: <http://linkinghub.elsevier.com/retrieve/pii/ S0950329312001838>. Accessed: Mar, 1, 2016. doi: 10.1016/j. foodqual.2012.08.016.

ARSLAN, B.; SOYER, A. Effects of chitosan as a surface fungus inhibitor on microbiological, physicochemical, oxidative and sensory characteristics of dry fermented sausages. Meat Science, 2018. v.145, n. April, p.107-113. Available from: <https://doi. org/10.1016/j.meatsci.2018.06.012>. Accessed: Aug. 8, 2019. doi: 10.1016/j.meatsci.2018.06.012.

BERTOL, T. M. et al. Rosemary extract and celery-based products used as natural quality enhancers for colonial type salami with different ripening times. Ciência e Tecnologia de Alimentos, 2012. v.32, n.4, p.783-792. Available from: $<$ https:// doi.org/10.1590/S0101-20612012005000110>. Acessed: May, 30, 2019. doi: 10.1590/S0101-20612012005000110.

BIS-SOUZA, C. V. et al. Volatile profile of fermented sausages with commercial probiotic strains and fructooligosaccharides. Journal of Food Science and Technology, 2019. Available from: $<$ https://link.springer.com/article/10.1007/s13197-019-04018-8>. Accessed: Oct. 14, 2019. doi: 10.1007/s13197-019-04018-8.

BRASIL. Instrução Normativa $n^{\circ} 22$ de 31 de julho de 2000. Regulamento Técnico de Identidade de Qualidade de Salame. Diário Oficial da União, Brasília, 2000.

CIROLINI, A. et al. Fermented italian sausage elaborated with native starter cultures. Ciência e Tecnologia de Alimentos, 2010. v.30, p.171-179. Available from: <http://www.scielo.br/scielo. php? script $=$ sci_arttext\&pid $=$ S0101-20612010000500026>. Accessed: May, 30, 2019. doi: 10.1590/S010120612010000500026.

CRUXEN, C. E. Dos S. et al. Development of fermented sausage produced with mutton and native starter cultures. LWT- Food Science and Technology, 2018. v.95, n. January, p.23-31. Available from: <https://doi.org/10.1016/j.lwt.2018.04.060>. Accessed: Sep. 23, 2019. doi: 10.1016/j.lwt.2018.04.060.

DALLA-SANTA, R. O. et al. Microbiota of sausages obtained by spontaneous fermentation produced in the South of Brazil. Ciência e Tecnologia de Alimentos, 2012. v.32, n.4, p.653-660. Available from: <https://doi.org/10.1590/S010120612012005000117>. Accessed: May, 30, 2019. doi: 10.1590/ S0101-20612012005000117.

FRANÇOIS, P. et al. Physico-chemical and sensorial properties of fermented sausages formulated with different proportions of 
meat from swine and culling ewes. Ciencia Rural, 2009. v.39, n.9, p.2584-2589. Available from: <https://doi.org/10.1590/S010384782009000900031>. Accessed: Oct. 23, 2019. doi: 10.1590/ S0103-84782009000900031.

GOTTARDO, E. T. et al. Artisanal fermented sausages as vehicles of pathogenic microorganisms of public health importance. B.CEPPA, 2011. v.29, n.1, p.97-102. Available from: <http:// dx.doi.org/10.5380/cep.v29i1.22761>. Accessed: Aug. 8, 2019. doi: $10.5380 /$ cep.v29i1.22761.

HAMMES, W. P.; KNAUF, H. J. Starters in the Processing of Meat Products. Meat science, 1994. v.36, p.155-168. Available from: $<\mathrm{http} / / /$ dx.doi.org/10.1016/0309-1740(94)90039-6>. Accessed: Jun. 6, 2019. doi: 10.1016/0309-1740(94)90039-6.

ISO 8589:2007.(2007). Sensory Analysis - General Guidance for the design of the test rooms. Switzerland.

KÜHNE, B. et al. Innovation in traditional food products in Europe: Do sector innovation activities match consumers ' acceptance? Food Quality and Preference, 2010. v.21, n.6, p.629-638. Available from: <http://dx.doi.org/10.1016/j. foodqual.2010.03.013>. Accessed: May, 30, 2019. doi: 10.1016/j. foodqual.2010.03.013.

LORENZO, J. M.; et al. Effect of commercial starter cultures on physicochemical characteristics, microbial counts and free fatty acid composition of dry-cured foal sausage. Food Control, 2014. v.46, p.382-389. Available from: <https://doi.org/10.1016/j. foodcont.2014.05.025>. Accessed: Mar, 31, 2020. doi: 10.1016/j. foodcont.2014.05.025

MARANGONI, C.; MOURA, N. Antioxidant activity of essential oil from Coriandrum Sativum L . in Italian salami. Ciencia e tecnologia de alimentos, 2011. v.2009, n.004039, p.124-128. Available from: <https://doi.org/10.1590/S010120612011000100017>. Accessed: May, 30, 2019. doi: 10.1590/ S0101-20612011000100017.

MARANGONI , C.; MOURA, N. F. De. Sensory profile of Italian salami with coriander ( Coriandrum sativum L .) essential oil. Ciencia e tecnologia de alimentos, 2011. v.31, n.1, p.119-123. Available from: <https://doi.org/10.1590/S010120612011000100016>. Accessed: May, 30, 2019. doi: 10.1590/ S0101-20612011000100016.

MINIM, V. P. R. Sensory Analysis: Consumers studies, 2006 Viçosa: Ed UFV. 225p.
PARUSSOLO, G. et al. Fungi in air, raw materials and surface of dry fermented sausage produced in Brazil. LWT- Food Science and Technology, 2019. v.108, n. March, p.190-198. Available from: $<$ https://doi.org/10.1016/j.lwt.2019.03.073>. Accessed: Sep. 23, 2019. doi: 10.1016/j.1wt.2019.03.073.

PÉREZ-ALVAREZ, J. A. et al. Physicochemical characteristics of Spanish-type dry-cured sausage. Food Research Internatinal, 1999. v.32, p.599-607. Available from: <https://doi.org/10.1016/ S0963-9969(99)00104-0>. Accessed: Jun. 10, 2019. doi: 10.1016/ S0963-9969(99)00104-0.

PRADO, N. et al. Physicochemical, sensory and microbiological characterization of Asturian Chorizo , a traditional fermented sausage manufactured in Northern Spain. Meat Science, 2019. v.156, n. April, p.118-124. Avaible from: <https://doi. org/10.1016/j.meatsci.2019.05.023>. Accessed: May, 30, 2019. doi: 10.1016/j.meatsci.2019.05.023.

RASON, J.; DUFOUR, E.; LEBECQUE, A. Diversity of the sensory characteristics of traditional dry sausages from the centre of France : Relation with regional manufacturing practice. Food Quality and Preference, 2007. v.18, p.517-530. Avaible from: $<$ https://doi.org/10.1016/j.foodqual.2006.07.002 >. Accessed: May, 30, 2019. doi: 10.1016/j.foodqual.2006.07.002.

SIPP, M. D.; TONIAL, I. B. Chemical, physical-chemical characteristics and microbiological quality of colonial sausage produced and marketed in the micro region of the municipality of Itapejara d'Oeste / PR. Brazilian Journal of Food Research, 2017. v.8, n.1, p.142-155. Available from: $<$ http://doi.org/10.3895/rebrapa.v8n1.3839>. Accessed: Aug. 8, 2019. doi: 10.3895/rebrapa.v8n1.3839.

TAPP III, W. N.; et al. How is the instrumental color of meat measured? Meat science, 2011. v.89, n.1, p.1-5. Avaible from: $<$ http://dx.doi.org/10.1016/j.meatsci.2010.11.021>. Accessed: Aug. 8, 2019. doi: 10.1016/j.meatsci.2010.11.021.

YUCA, B. et al. Effects of beta-glucan addition on the physicochemical and microbiological characteristics of fermented sausage. Journal of Food Science and Technology, 2019. v.56, n.7, p.3439-3448. Avaible from: <http://doi.org/10.1007/s13197-019-03830-6>. Accessed: Oct. 14, 2019. doi: 10.1007/s13197-019-03830-6.

ZANARDI, E. et al. Lipid and color stability of Milano-type sausages: effect of packing conditions. Meat science, 2002. v.61, p.7-14. Avaible from: <http://doi.org/ 10.1016/s03091740(01)00152-8>. Accessed: Jul. 29, 2019. doi: 10.1016/s03091740(01)00152-8. 